\title{
A review on radiofrequency, microwave and high-intensity focused ultrasound ablations for hepatocellular carcinoma with cirrhosis
}

\author{
Tan To Cheung, Ka Wing Ma, Wong Hoi She \\ Department of Surgery, The University of Hong Kong, 102 Pok Fu Lam Road, Hong Kong, China \\ Contributions: (I) Conception and design: TT Cheung; (II) Administrative support: TT Cheung; (III) Provision of study materials or patients: TT \\ Cheung; (IV) Collection and assembly of data: KW Ma, WH She; (V) Data analysis and interpretation: KW Ma, WH She; (VI) Manuscript writing: \\ All authors; (VII) Final approval of manuscript: All authors. \\ Correspondence to: Dr. Tan To Cheung. The University of Hong Kong, 102 Pok Fu Lam Road, Hong Kong, China. Email: tantocheung@hotmail.com.
}

\begin{abstract}
Importance: Hepatocellular carcinoma (HCC) is usually accompanied by liver cirrhosis, which makes treatment of this disease challenging. Liver transplantation theoretically provides an ultimate solution to the disease, but the maximal surgical stress and the scarcity of liver graft make this treatment option impossible for some patients. In an ideal situation, a treatment that is safe and effective should provide a better outcome for patients with the dilemma.

Objective: This article aims to give a comprehensive review of various types of loco-ablative treatment for HCC.

Evidence Review: Loco-ablative treatment bridges the gap between surgical resection and transarterial chemotherapy. Various types of ablative therapy have their unique ability, and evidence-based outcome analysis is the most important key to assisting clinicians to choose the most suitable treatment modality for their patients.

Findings: Radiofrequency ablation (RFA) has a relatively longer history and more evidence to support its effectiveness. Microwave ablation (MWA) is gaining momentum because of its shorter ablation time and consistent ablation zone. High-intensity focused ultrasound (HIFU) ablation is a relatively new technology that provides non-invasive treatment for patients with HCC. It has been carried out at centers of excellence and it is a safe and effective treatment option for selected patients with HCC and liver cirrhosis.
\end{abstract}

Conclusion and Relevance: Selective use of different loco-ablative therapies will enhance clinicians' treatment options for treatment of HCC.

Keywords: High-intensity focused ultrasound (HIFU); hepatocellular carcinoma (HCC); liver cancer; radiofrequency ablation (RFA); microwave ablation (MWA); survival; non-invasive treatment; ablation; cirrhosis; complication

Submitted Jul 04, 2019. Accepted for publication Sep 19, 2019.

doi: $10.21037 /$ hbsn.2020.03.11

View this article at: http://dx.doi.org/10.21037/hbsn.2020.03.11

\section{Introduction}

Percutaneous thermal ablation has been one of the treatment options for patients with hepatocellular carcinoma (HCC) and cirrhosis $(1,2)$. Radiofrequency ablation (RFA), high-intensity focused ultrasound (HIFU) ablation and microwave ablation (MWA) are among the popular modes of ablation. According to the Barcelona
Clinic Liver Cancer treatment algorithm, ablation is used for HCC of stage 0 and stage 1 only. However, in real-life practice, especially in Asian regions where the Barcelona Clinic Liver Cancer treatment algorithm is not strictly followed, ablative treatment plays an important role in the management of HCC at different stages. This article aims to review the characteristics, advantages and disadvantages 
of RFA, HIFU and MWA as ablative treatment options for HCC with cirrhosis. We present the following article in accordance with the Narrative Review reporting checklist (available at https://hbsn.amegroups.com/article/ view/10.21037/hbsn.2020.03.11/rc).

\section{Working mechanism of RFA and heat-sink effect}

Radiofrequency electric current of $400-500 \mathrm{KHz}$ is transmitted to the tumor cell through the distal end of the uninsulated part of the puncturing needle. Frictional heat energy is generated from the vibration of the ionic particles around the needle, and a temperature of $50-100{ }^{\circ} \mathrm{C}$ is produced. Tumor cells are killed as protein denatures under this high temperature (1). The radiofrequency current is conducted uniformly in a spherical manner if the surrounding tissue is of low impedance. Impedance will increase as tissue chars and vaporized gas accumulated, limiting the spread of heat energy. Most modern multi-array RFA electrodes can achieve an ablation zone of around $5 \mathrm{~cm}$. As a 1-cm ablation margin is recommended, tumors $<3 \mathrm{~cm}$ should be adequately ablated by RFA. Complete tumor ablation can be achieved in over $80 \%$ of cases (2). Since RFA works by inducing heat effect leading to tumor necrosis, when the tumor is located next to a major vessel (i.e., major branch of the portal vein or hepatic vein), the lower temperature of blood "cools down" the tumor abutting the vessel, leading to incomplete ablation. This heat dissipating phenomenon is known as the "heat sink" effect (3).

\section{Comparison of RFA with some other non-surgical treatment modalities}

Apart from physical means of ablative therapy, chemical ablation using ethanol, acetic acid (4) and sodium hydroxide (5) has been proposed. Percutaneous ethanol infusion has been the more popular chemical ablation. It works by the dehydrating property of absolute alcohol. After injection of ethanol to the tumor, diffusion of ethanol takes place along the concentration gradient, and tumor cells are killed by denature of protein and tumor vessels are thrombosis (6). Percutaneous ethanol infusion is generally safe and effective for tumors $<3 \mathrm{~cm}$ although treatment of HCC up to $5 \mathrm{~cm}$ has been reported (7-9). When compared to RFA, percutaneous ethanol infusion has inferior survival outcomes as evidenced by many studies including a few meta-analyses (10-13). This is probably related to the presence of intratumoral septa and capsules, leading to uneven distribution of ethanol and hence a higher local recurrence rate.

Cryo-ablation is another physical means of ablative therapy. With sub-zero temperature, crystallization of water at intracellular and extracellular spaces leads to destruction of cellular structures (14). There were a few small series suggesting the effectiveness of cryo-ablation for primary $\operatorname{HCC}(15,16)$ and recurrent $\operatorname{HCC}(17)$. Nonetheless, the need for laparotomy for probe access, a higher complication rate $(16,18-20)$ and inferior oncological outcomes are unfavorable when compared with RFA (21), and hence cryo-ablation has become obsolete in most centers nowadays.

\section{Efficacy of RFA versus resection in treatment of HCC}

Chen et al. randomized 180 patients who had $\mathrm{HCC} \leq 5 \mathrm{~cm}$ to either percutaneous RFA or resection and saw no significant difference in overall survival or recurrencefree survival between the two treatment arms (22). In a randomized study by Feng et al. including patients with $\mathrm{HCC}<4 \mathrm{~cm}$ and $\leq 2$ nodules who received either ablation or resection, again, no survival benefit was demonstrated by either arm (23). Huang et al. randomized 230 HCC patients within the Milan criteria (24) to either RFA or resection, and patients who received resection had significantly better 5 -year overall survival $(76 \%$ vs. $55 \%, \mathrm{P}=0.001)$ and recurrence-free survival (55\% vs. 34\%, $\mathrm{P}=0.017$ ) (25). More recent studies focused on smaller HCCs. Liu et al. performed a propensity score matching comparison of these two treatment modalities for HCCs $<2 \mathrm{~cm}$ and found that resection was a superior treatment approach as shown by the superior 5 -year recurrence-free survival ( $48 \%$ vs. $18 \%, \mathrm{P}<0.001)$ and overall survival $(80 \%$ vs. $66 \%$, $\mathrm{P}=0.034)(26)$. Another propensity score matching analysis found no difference in overall survival but significant inferiority in recurrence-free survival in the RFA group (HR 1.75; $\mathrm{P}<0.001)$ (27). Another recent multi-center study using the Surveillance, Epidemiology, and End Results database suggested that the use of RFA should be limited to HCCs $<3 \mathrm{~cm}$ and that tumors $>3 \mathrm{~cm}$ should be treated by resection or transplantation for better oncological outcomes (28). It is difficult to draw a conclusion from these studies as they had different inclusion criteria, and many of these studies did not consider possible confounders such as tumor characteristic, location of tumor, type of 
electrode (single or cluster needles), and number of ablation cycle used in the RFA group. Further evidence from a multi-center randomized control study with standardized inclusion criteria is needed. It is generally considered that resection produces better oncological outcomes than RFA. Nonetheless, percutaneous RFA has been shown to be associated with better post-treatment quality of life when compared with resection (29), making RFA a reasonable choice for frail patients.

\section{Role of RFA in treating larger HCCs and HCCs in difficult locations}

During the process of tumor ablation, charring of tumor tissue increases the impedance of energy transmission and hence limits the size of ablation zone. Although satisfactory survival outcomes have been demonstrated (30,31), RFA for resectable HCCs of over $5 \mathrm{~cm}$ is generally not preferred (32-34). Different techniques have been introduced to improve the rate of complete tumor ablation and safety profile. For large tumors, multiple overlapping ablation can be used to increase the effective ablation zone (35). For lesions abutting a vascular structure, application of Pringle maneuver during ablation mitigates the "heat sink" effect (36). For lesions close to the hilum or biliary structure, infusion of chilled saline into the biliary system during ablation can protect the bile duct from heat injury $(37,38)$. A cooled-tip electrode and intermittent energy generator can be used to reduce char formation around the electrode (39). Use of clustered or antenna-like needle configuration can increase the ablation zone to $7 \mathrm{~cm}(40,41)$. It has been proposed that sequential use of transarterial chemoembolization (TACE) before RFA can improve the outcomes of HCC treatment $(42,43)$. A recent meta-analysis suggested that combining TACE and RFA could result in superior survival outcomes when compared to using RFA alone in treating large HCCs (44).

\section{Pre-transplant bridging and down-staging therapies using RFA}

Due to the scarcity of liver graft, waitlisted HCC patients are expected to have a dropout rate of $20-30 \%$ due to disease progression (45-47). Many centers (including ours) offer bridging therapy to HCC patients when the waiting time is expected to be $>6$ months (48). Some centers used RFA as a bridging therapy and the dropout rate was brought down to $<10 \%(49,50)$. Furthermore, response to bridging therapy has been shown to be associated with the rate of post-transplant recurrence of HCC. Chan et al. found that tumor necrosis of $60 \%$ or more was an independent factor associated with a lower rate of post-transplant recurrence (51).

Down-staging therapy with the use of RFA provides the last hope of transplantation for patients who initially presented with beyond-criteria HCC. Several centers practiced down-staging protocols for HCC patients beyond standard criteria, and the rates of successful down-staging and transplantation were $56-90 \%(52-54)$ and $44-78 \%$ respectively (52-55). Moreover, the long-term oncological outcomes in these patients were not compromised when compared with those in HCC patients within standard criteria at presentation.

\section{Role of RFA in treating ruptured HCCs}

RFA has become a treatment of choice for recurrent HCC, with a 5 -year overall survival rate of $18-40 \%(56,57)$. In a meta-analysis comparing resection, RFA and TACE for recurrent HCC, patients in the RFA group had the best median 5-year overall survival, although the difference did not reach statistical significance (58).

Spontaneous tumor rupture is one of most dreadful complications of HCC and it happens in $3-10 \%(59,60)$ of patients. TACE has been the established first-line treatment. However, RFA comes into play when TACE fails to stop bleeding. With regard to the role of RFA in the management of ruptured HCCs, our center has published a 20-year retrospective series. In this study, we found that treating ruptured HCCs with open RFA for hemostasis was an independent factor for better overall survival (HR 0.41, 0.24-0.79) (59).

\section{Complications of RFA as a treatment of HCC}

Complications after RFA is uncommon. Most patients can be discharged after overnight observation after percutaneous RFA. The overall complication rate is $<10 \%$ and the mortality rate is around $0.5 \%$ (61-63). Some common non-life-threatening complications are liver abscess, pleural effusion, pneumothorax, and subscapular hematoma. Other rarer life-threatening complications include liver failure, portal vein thrombosis, and bowel perforation. Good patient and operator selection is the only way to avoid mishaps. 
Table 1 Treatment outcomes of percutaneous RFA in patients with cirrhosis

\begin{tabular}{lccccccc}
\hline Study & Year & $\begin{array}{c}\text { No. of } \\
\text { patients }\end{array}$ & Cirrhosis & Tumor size & $\begin{array}{c}\text { Complete } \\
\text { response }\end{array}$ & 3-year survival & Complication rate \\
\hline $\begin{array}{l}\text { Brunello } \\
\text { et al. (65) }\end{array}$ & 2008 & 70 & Mainly Child A & $<3 \mathrm{~cm}$ & $95.7 \%$ & $63 \%$ & $14.2 \%$ (all complications) \\
Lin et al. (66) & 2005 & 62 & Mainly Child A & $<3 \mathrm{~cm}$ & $92.8 \%$ & $74 \%$ & $4.8 \%$ (major complications) \\
Seror et al. (67) & 2006 & 57 & Child A only & $<3.5 \mathrm{~cm}$ & - & $91.2 \%$ (2-year) & $15 \%$ (major complications) \\
Shiina et al. (68) & 2005 & 118 & Mainly Child A & $<3 \mathrm{~cm}$ & $100 \%$ & $81 \%$ & $5.1 \%$ (major complications) \\
Feng et al. (23) & 2012 & 84 & Mainly Child B & $<3 \mathrm{~cm}$ & $94 \%$ & $67.2 \%$ & $9.5 \%$ (all complications) \\
Liu et al. (26) & 2016 & 100 & Mainly Child A & Milan criteria & - & $67.2 \%$ & $11 \%$ (all complications) \\
Ng et al. (69) & 2017 & 109 & Mainly Child A & Milan criteria & $94.4 \%$ & $82.3 \%$ & $4.6 \%$ (severe complications) \\
\hline
\end{tabular}

\section{Limitations of RFA}

During RFA treatment, heat energy generated by highfrequency alternating currents $(460-480 \mathrm{kHz})$ targeted at the living tissues causes protein denaturation at a temperature of $60^{\circ} \mathrm{C}$ through ionic vibration. Coagulative necrosis of the target lesion follows (64). The initial results of percutaneous RFA for small HCCs were encouraging: the complete tumor response rate was high and the complication rate was as low as $5 \%$. Table 1 lists the outcomes of percutaneous RFA for small HCCs $(23,65-69)$. However, these data can be misleading, as most of the patients did not have decompensation of cirrhosis. Deaths after percutaneous RFA for liver cancer in non-cirrhotic patients have been reported. The reported mortality rate were between $0.3 \%$ and $1.6 \%$ (70-72). In addition, the efficacy of RFA in treating large tumors is still questionable. Although several reports showed that it was feasible to use RFA with multiple processes and overlapping ablation zones to treat large liver tumors, the high recurrence rates did not favor it as a primary treatment tool for these tumors $(41,73,74)$.

Open RFA may be risky for patients with advanced cirrhosis because of thrombocytopenia and portal hypertension. On the other hand, percutaneous RFA requires a very high level of skill if it is used to treat these tumors: deeply seated tumors, tumors in the caudate lobe, and tumors located at the dome of liver where diaphragmatic injury may result as a collateral damage due to the ablation procedure. Moreover, percutaneous RFA is contraindicated in the presence of ascites because of the increased chance of hemoperitoneum and liver failure.

An effective locoregional treatment with a non-invasive nature could probably bridge the treatment gap between percutaneous RFA and TACE for cirrhotic HCC patients.

\section{History of HIFU treatment}

HIFU ablation is a non-invasive treatment modality that uses an extracorporeal source of ultrasound energy focused at a particular point. This technique was first described by Lynn et al. in 1942 (75). Clinical use of HIFU started with the concept of utilizing high-energy ultrasound beam to induce hyperthermia and tissue damage as proposed by the Fry brothers in USA in 1950s. The initial experiments were to evaluate this treatment option for patients with Parkinson disease $(76,77)$. With not very successful outcomes, the research interest died down, but the enthusiasm was aroused again in the 1990s when a more powerful output unit was designed. In 1997, Wang made use of the re-designed unit of HIFU machine and demonstrated that effective destruction of liver tissue could be performed in an animal model (78). This report initiated a cascade of clinical studies on the possibility of HIFU treatment for liver tumors.

\section{Physical properties of HIFU treatment}

The modern HIFU treatment unit has a significantly higher time-averaged intensity in the focal region of the ultrasound transducer, when compared with typical diagnostic ultrasound. HIFU ablation utilizes a unique frequency of ultrasound wave of $0.8-3.5 \mathrm{MHz}$, which can be focused at a distance from the therapeutic transducer. This causes vibration of the particles inside the cells, and the heat generated as a result raises the temperature in the tissue rapidly to $60{ }^{\circ} \mathrm{C}$ or higher, causing coagulative necrosis within a few seconds. Energy-focusing results 
in high intensity at a specific location and over a small volume. Temperature outside the focus point remains static as particle oscillation remains minimal. In addition to thermal effects, cavitation effects, microstreaming and radiation forces all contribute to cell death. At high intensity, ultrasound can result in tissue heating and necrosis, cell apoptosis, and cell lysis. Cavitation, as a cause of tissue damage, is a result of the presence of small gaseous nuclei existing in subcellular organelles and fluid in tissue that can expand and contract under the influence of the acoustic pressure. Gas is drawn out of the solution during rarefaction, creating bubbles. These bubbles may remain relatively stable and simply oscillate or they may collapse spontaneously, causing mechanical stresses and generating heat in the environment (79). There are different treatment machines manufactured by different companies. In general, a HIFU treatment unit is composed of an ablation unit, an energy-generating unit, and a monitoring unit for the change in ablation. HIFU treatment machines can be classified into MRI-guided HIFU (MRgHF) and ultrasound-guided HIFU (USgHF) according to the monitoring modality. Currently, USgHIFU is approved for use in Bulgaria, Italy, Japan, South Korea, Malaysia, Mexico, the UK, Russia, Romania, Spain and China (including the Hong Kong SAR) for the treatment of uterine fibroids and cancers of the brain, breast, liver, bone and prostate. On the other hand, MRgHIFU is an approved therapeutic procedure for treating uterine fibroids in Asia, Europe, Australia, Israel, Canada and the USA (approved by U.S. Food and Drug Administration).

As ultrasound energy travels much better in water than in air, the presence of ascites in HCC patients actually facilitates energy propagation to the targeted tumor.

\section{HIFU for small HCCs}

In 2001, Wu et al. reported that effective destruction of tumor cells was achieved in a group of HCC patients who received HIFU two weeks before resection. In the treated areas, irreversible cell death (nuclear pyknosis, debris, and dissolution) was observed. Blood sinusoids collapsed with endothelial cell damage. Electronic microscopic examination showed that there were distorted tumor cells with severe destruction of cell organelles and nuclei in the treated area. Disintegration of cell membrane and nuclear membrane, as well as nucleus disruption, was generally observed (80). Studies reporting successful HIFU ablation in patients with non-resectable small HCCs began to appear. $\mathrm{Ng}$ et al. demonstrated that the initial treatment response in patients with HCCs with a median tumor size of $2.2 \mathrm{~cm}$ was promising. The primary complete ablation rate was $79.5 \%$. It increased from $66.6 \%$ in the initial series to $89.2 \%$ in the last 28 patients. The primary technique effectiveness for tumors $<3.0 \mathrm{~cm}$ was $90.6 \%$, whereas that for tumors $\geq 3.0 \mathrm{~cm}$ was $58.8 \%$ (81). Xu et al. in a clinical study involving 145 patients demonstrated that HIFU ablation was an effective treatment for HCC. The 2-year survival rates in patients with stage-I, stage-II and stageIII HCC were $80 \%, 51.4 \%$ and $46.5 \%$ respectively (82). Cheung et al. demonstrated that HIFU ablation was an effective alternative to percutaneous RFA for small HCCs. In the HIFU group, there were significantly more patients with Child-B cirrhosis (35\%). In patients with HCCs $<3 \mathrm{~cm}$, the 1 and 3 -year survival rates after HIFU treatment were $81.2 \%$ and $79.8 \%$ respectively. The $1-$ and 3 -year diseasefree survival rates were $62.4 \%$ and $34.1 \%$ respectively (83).

\section{HIFU for large HCCs}

The prognosis for larger unresectable HCCs is very poor $(84,85)$, and TACE has been a suggested treatment for this group of patients (86-88). However, the median patient survival after TACE has not been very satisfactory. The 3 -year survival rate after TACE in patients with HCCs $>5 \mathrm{~cm}$ was reported to be $<31 \%$ (89). RFA is considered not suitable for patients who have large HCCs, especially if they also have advanced cirrhosis. The non-invasive nature of HIFU is an advantage for patients with advanced cirrhosis. Research has been carried out to investigate whether HIFU ablation is a suitable treatment for large HCCs in the presence of cirrhosis. Wu et al. reported that HIFU could be safely used in cirrhotic patients with advanced HCC. In a study involving 55 patients with a median tumor size of $8.1 \mathrm{~cm}(4-14 \mathrm{~cm})$, the overall survival rates at 6,12 and 18 months were $86.1 \%, 61.5 \%$ and $35.3 \%$ respectively. No severe complications were reported (90). In a study involving 151 patients with advanced HCC, the complete response and partial response rates for HIFU treatment were $28.5 \%$ and $60.3 \%$ respectively in patients with advanced HCC. The 1-year and 2-year survival rates were $50 \%$ and $30.9 \%$ respectively in these patients and $3.4 \%$ and $0 \%$ respectively in patients who received maximal conservative treatment only (91). Cheung et al. reported that the complete response rate of tumors $>5 \mathrm{~cm}$ was $50 \%$, and the 1-, 3 - and 5 -year survival rates were $84.6 \%$, $49.2 \%$ and $32.3 \%$ respectively (92). Incomplete ablation 
likely happens with larger tumors. In order to improve the survival of patients with larger tumors, clinicians have tried to combine TACE and HIFU ablation. Wu et al. randomized 50 patients with HCCs $>10 \mathrm{~cm}$ to two treatment groups: TACE alone and TACE with HIFU. A survival benefit was seen in the latter group. Patients with stage-IV HCC in this group had a 1-year survival rate of $42.9 \%$, versus $0 \%$ in their counterparts (93). $\mathrm{Li}$ et al. also compared these two modalities (TACE alone and TACE with HIFU) for unresectable large HCCs. They randomized 89 patients with unrespectable large HCCs to these two treatment groups. A significantly higher tumor response rate and a survival benefit were seen in the group having combined treatment. The 1-, 2- and 3-year overall survival rates in this group were $72.7 \%, 50.0 \%$ and $31.8 \%$ respectively, versus $47.2 \%, 16.7 \%$ and $2.8 \%$ respectively in their counterparts (94).

\section{HIFU for tumors in difficult positions}

Proximity of tumor to large blood vessels plays a significant role in heat transmission. Blood flow protects the vessel wall from damage, but it also acts as a "heat sink" and cools nearby tissue, limiting coagulative potential (95). The potential heat-sink effect of HIFU has been investigated. In a study involving 39 patients with 42 tumors $(1.5-22 \mathrm{~cm}$; median, $7.4 \mathrm{~cm}$ ) close to major hepatic vessels, patients with smaller tumors had better tumor response to HIFU treatment. The complete response rate was $50 \%$ and the partial response rate was $50 \%$ (96). The heat-sink effect was minimal due to the extracorporeal mode of energy delivery. Unlike percutaneous RFA where heat energy dissipates from the radius of the active treatment electrode, HIFU delivers heat energy at a precise focus point of around $1 \mathrm{~cm}$ in diameter. HIFU can theoretically ablate tumors in difficult locations. With the aid of artificial pleural effusion with normal saline, effective ablation can be achieved near the diaphragm or the heart where percutaneous RFA is technically impossible $(97,98)$.

\section{HIFU ablation as a bridging therapy}

Patients awaiting liver transplantation in general have relatively poor liver function. They may present with gross ascites and hyperbilirubinemia, which are contraindications to TACE. Since the liver donation rate is very low in most Asian regions, these patients need an effective bridging therapy to prevent the progression of HCC and dropping out while waiting for a liver graft. HIFU ablation can potentially provide a suitable bridge in this context. HIFU ablation is well tolerated in cirrhotic HCC patients. After the first report of successful HIFU ablation as a bridging therapy for patients awaiting transplantation (97), the Hong Kong group started using it as a treatment modality for waitlisted HCC patients (99). The interim results with a small sample number showed that HIFU ablation is a safe and promising treatment in waitlisted patients. None of the patients developed liver failure after treatment. The treatment can potentially reduce the dropout rate in areas where the liver donation rate is low.

\section{Complications of HIFU ablation}

Complications of HIFU ablation are mainly related to the thermal injury resulting from the focused ultrasound. It can cause damage to internal organs if the focus point is misplaced or it can cause damage to the tissue along the pathway of the HIFU energy penetration. Most patients may experience first-degree skin burn and pain after treatment but most of these conditions are self-limiting. However, severe complications, including ablation of the small bowel in the surrounding area requiring laparotomy, have been reported (100). Xu et al. showed that HIFU treatment was a well-tolerated treatment option for cirrhotic HCC patients. First-degree skin burn occurred in $37.2 \%$ of the patients, second-degree skin burn occurred in $31.7 \%$ of the patients and third-degree skin burn occurred in $2.1 \%$ of the patients. No complication related to liver function decompensation was reported (82). Cheung et al. reported that 13 patients developed complications after HIFU treatment for HCC. Most of the complications were associated with skin injuries. One patient developed transient hyperbilirubinemia and one patient developed liver abscess that did not require drainage. More than one-third of patients had Child-B cirrhosis. There was no mortality reported (101). Table 2 summarizes the results of HIFU treatment in cirrhotic HCC patients.

\section{MWA-aim of the treatment}

The ultimate mechanism of tumor destruction by MWA is thermally induced coagulative necrosis. Heat is generated by high-frequency ( $>900 \mathrm{MHz}$ ) electromagnetic energy via interaction with protons predominately residing within water molecules, which causes them to flip their electrical charge (hydrogen has a positive charge and oxygen 
Table 2 Summary of HIFU treatment in patients with HCC and cirrhosis

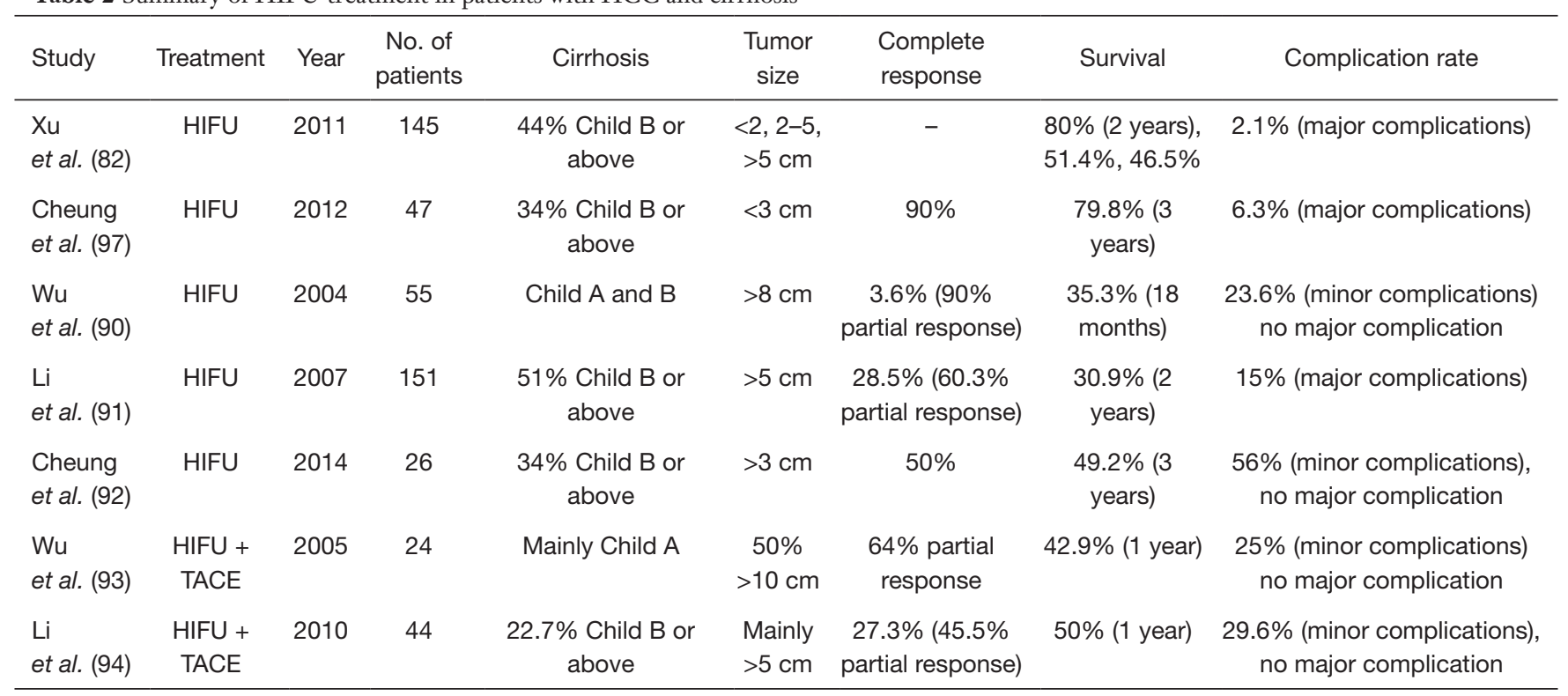

negative) $2-5$ billion times/s, thereby generating friction and heat (102).

MWA can be performed in open or laparoscopic approach or percutaneously under the guidance of ultrasound or computed tomographic scan. It allows broader fields of power density, and is able to create more uniform and larger ablation zones, thereby reducing or eliminating the heat-sink effect (especially when adjacent to large vessels). It has several technical advantages over RFA, including predictable ablation zone, faster ablative time, and non-susceptibility to current and thermal "heat sinks" within the ablation field (103).

Microwave coagulation therapy was first introduced as a treatment modality in Japan (104-106) and was used mainly for hemostasis or coagulation during liver resection $(107,108)$. The advantages of MWA include larger volume of cellular necrosis, reduced procedure time, higher temperature delivered to the target lesion, possibility of simultaneous use of multiple antennae, fewer intraprocedural complications, and efficacy on lesions with a cystic component and/or in proximity to vascular structures with reduced heat-sink effect $(102,109,110)$.

\section{Physical properties of MWA}

This surgical tool is based on the principle that microwave irradiation of tissue with a frequency of $2,450 \mathrm{MHz}$ (corresponding wavelength of $12 \mathrm{~cm}$ ) via a monopolar antenna produces heat due to energy produced by the vibration of polar molecules in protein and water $(107,108,111)$. The generation of heat is limited to the electromagnetic field around the antenna, and the coagulation field is determined by the relationship between antenna length and tissue permittivity. Each coagulation session consists of 30-45 s of coagulation and $5 \mathrm{~s}$ of dissociation.

\section{Microwave tissue coagulator}

The microwave tissue coagulator system consists of a microwave generator [which generates the power required and monitors energy delivery to the patient $(112,113)]$, a hand piece, and a reusable needle antenna that can be adjusted in length $(10-45 \mathrm{~mm})$. There is an attached device that can change the antenna angle in $90^{\circ}$, usually a semi-rigid coaxial cable that emits microwave radiation from its exposed (uncovered by the outer conductor) distal end, embedded into a needle-like device. There is also a power transmission line linking the energy source output ports to the antennae.

\section{MWA for small HCCs}

Early-stage HCC is defined as a single HCC lesion $\leq 5 \mathrm{~cm}$ in diameter or three nodules $\leq 3 \mathrm{~cm}$ in diameter, according to the Barcelona Clinic Liver Cancer staging system (114). For early HCC, thermal ablation has been gaining acceptance (22,115-118), and RFA and resection achieve similar treatment 
outcomes (22,116-118). For HCC $<2 \mathrm{~cm}, \mathrm{RFA}$ can achieve a comparable 5-year survival rate of 70\% (26,32,119-123).

MWA has also been used for early or very early HCC. $\mathrm{Xu}$ et al. reported non-inferior treatment results of MWA when compared to RFA in treating very early HCC, with a 5 -year survival rate of $78.3 \%$ vs. $73.3 \%$ (124). Similar outcomes were also observed in treating early HCC with MWA versus RFA, although further subgroup analysis showed that MWA had better outcomes in treating HCCs $>3.5 \mathrm{~cm}$ (125). The additional use of laparoscopic thermal ablation might allow precise localization and benefit from the laparoscopic surgical approach, while similar survival was achieved in treating tumors $\leq 3 \mathrm{~cm}$ with MWA versus RFA (126). Unfortunately, the use of the thermal ablative modality, unlike surgical resection, is associated with a higher rate of early recurrence, particularly in patients having percutaneous ablation (127).

\section{MWA for large HCCs}

It is possible to consider microwave treatment as a curative therapy rather than a palliative treatment for large lesions because of its large ablative zone (128). In a study of MWA for HCCs $5-8 \mathrm{~cm}$, complete ablation rates from $73.1 \%$ to $87.5 \%$ were achieved (129). In another study of MWA for HCCs 3-7 cm, higher complete ablation rates up to 92.6\% were reported (130), despite the fact that $22.2 \%$ of the patients developed local recurrence, which is a common phenomenon in ablative therapy $(130,131)$. MWA can be an alternative treatment modality, especially for patients who are not fit for resection or transplantation, or when the tumor location is not ideal for RFA.

\section{MWA for tumors in high-risk locations}

High-risk locations are areas close $(<5 \mathrm{~mm})$ to the gallbladder, the gastrointestinal tract, the second bile duct or the third bile duct. The major complication rate resulting from RFA can be as high as $4.1 \%$ (132), including bile duct injury, biliary stricture, biloma, bilioperitoneum or biliopleural fistula in up to $12 \%$ of patients (133). While perforation of the gastrointestinal tract has been reported, the overall incidence was around $0.1-0.3 \%$ (134). The temperature dispersed from MWA can be set at as high as $60{ }^{\circ} \mathrm{C}$ for the gallbladder and bile duct and $55^{\circ} \mathrm{C}$ in areas close to the gastrointestinal tract. In a recent study, the complete ablation rate was $98.2 \%$ but some patients required more than one session to get complete ablation (135).
For tumors at the liver dome, thermal ablative therapy may be difficult because of potential complications; phrenic nerve/diaphragmatic injury, pneumothorax or peritoneal burn may occur if the tumor is close to the diaphragm, peritoneum or lung. Moreover, using ultrasound to localize tumors in this region may be difficult because of poor acoustic penetration due to overlying lung tissue (136). For these tumors, MWA guided by computed tomography is feasible, with the aid of artificial ascites to displace the liver dome from the right hemi-diaphragm (137).

HCC may present as exophytic tumor, in which a portion of the tumor goes beyond the margin of the liver and extrudes into the abdominal cavity. With insufficient normal liver parenchyma to surround it, it has the risks of rupture, seeding and hemorrhage when treated with thermal ablation (138). To minimize the complication risk, an antenna is inserted into the normal liver tissue and the vessel feeding the tumor, which should be ablated first so as to reduce the blood flow to the tumor before ablation of the main tumor bulk (139). Furthermore, the use of artificial pleural effusion or ascites can help to prevent adjacent viscera from heat injury $(140,141)$. With these measures, exophytic HCCs can be safely ablated by MWA.

\section{MWA as a bridging therapy}

Patients awaiting liver transplantation in general have relatively poor liver function. They may present with gross ascites and hyperbilirubinemia, which are contraindications to TACE. Since the liver donation rate is very low in most Asian regions, these patients need an effective bridging therapy to prevent the progression of HCC and dropping out while waiting for a liver graft. TACE and percutaneous thermal ablation have been successful at prolonging survival of HCC patients and at bridging patients to transplantation (142-145). Microwave can be used in bridging therapy in this context. In a study by Zanus et al., six patients who had HCC (from single nodule to multifocal HCC) underwent MWA as a bridging therapy before transplantation. These patients did not have evidence of peritoneal or nodal HCC or histological signs of active neoplastic disease in the treated nodules. One patient died 15 days after transplantation due to sepsis and five patients were alive one year after transplantation without evidence of recurrence (146). Combination of treatment modalities have also been advocated (TACE with RFA or TACE with MWA). In a study by Vasnani et al., $>90.5 \%$ tumor coagulation was noted in excised livers treated by TACE with MWA, 
and complete tumor coagulation was noted in $53 \%$ of patients. The group having TACE with RFA had similar results (147). Combination therapy is safe and may offer further advantages such as control of micro-metastasis and more uniform ablation zones by MWA $(44,148)$. Studies involving more patients are needed to confirm the usefulness of MWA as a bridging therapy on its own or as a component in a combination bridging therapy. However, the reported explant histology showed a promising result. Further study is needed for confirmation.

\section{Complications of MWA}

Complications of MWA mainly arise from heat damage. A complication rate lower than RFA has been reported (149). Thermal injury to the bile duct may result in acute cholangitis or liver abscess formation. Insertion of antenna may result in intraperitoneal bleeding and liver hematoma formation. Liver decompensation is rarely seen, and the incidence can be reduced with better patient selection (149-154). Table 3 summarizes the outcomes of MWA in HCC patients.

Table 3 Summary of microwave ablation in patients with HCC and cirrhosis

\begin{tabular}{|c|c|c|c|c|c|c|c|c|}
\hline Study & Year & $\begin{array}{c}\text { No. of } \\
\text { patients }\end{array}$ & Cirrhosis & Tumor size & Tumor location & $\begin{array}{l}\text { Complete } \\
\text { response }\end{array}$ & Survival & Complication rate \\
\hline $\begin{array}{l}\text { Seki } \\
\text { et al. (150) }\end{array}$ & 1999 & 48 & $\begin{array}{c}56.3 \% \mathrm{~A} \\
41.7 \% \mathrm{~B} \\
2.1 \% \mathrm{C}\end{array}$ & $1.83 \pm 0.23 \mathrm{~cm}$ & NS & NS & $78 \%$ (5 years) & \\
\hline $\begin{array}{l}\text { Ohmoto } \\
\text { et al. (153) }\end{array}$ & 2009 & 49 & $\begin{array}{l}63.3 \% \mathrm{~A} \\
28.6 \% \mathrm{~B} \\
8.2 \% \mathrm{C}\end{array}$ & $1.7(0.8-2.0) \mathrm{cm}$ & NS & NS & $39 \%$ (4 years) & $\begin{array}{c}14 \% \text { (major } \\
\text { complications) }\end{array}$ \\
\hline $\begin{array}{l}\text { Ding } \\
\text { et al. (154) }\end{array}$ & 2013 & 113 & $\begin{array}{l}66.4 \% \mathrm{~A} \\
33.6 \% \mathrm{~B}\end{array}$ & $2.55 \pm 0.89 \mathrm{~cm}$ & $\begin{array}{c}7 \text { near major vessels, } \\
4 \text { near gallbladder, } 23 \\
\text { near diaphragm, } 8 \text { near } \\
\text { gastrointestinal tract }\end{array}$ & $98.5 \%$ & $\begin{array}{c}77.6 \% \text { (3 years), } \\
45.34 \pm 2.28 \text { months }\end{array}$ & $\begin{array}{c}2.7 \% \text { (major } \\
\text { complications) }\end{array}$ \\
\hline $\begin{array}{l}\text { Liu } \\
\text { et al. (131) }\end{array}$ & 2013 & 80 & $\begin{array}{c}85 \% \mathrm{~A}, 15 \% \\
\mathrm{~B}\end{array}$ & $3-8 \mathrm{~cm}$ & 19 near bile duct & $87.5 \%$ & $34.6 \%$ (5 years) & $\begin{array}{c}7.5 \% \text { (major } \\
\text { complications) }\end{array}$ \\
\hline $\begin{array}{l}\text { Zhang } \\
\text { et al. (145) }\end{array}$ & 2013 & 77 & $100 \% \mathrm{~A}$ & up to $5 \mathrm{~cm}$ & NS & $86.7 \%$ & $38.5 \%$ (5 years) & $\begin{array}{c}2.6 \% \text { (major } \\
\text { complications) }\end{array}$ \\
\hline $\begin{array}{l}\text { Groeschi } \\
\text { et al. (127) }\end{array}$ & 2014 & 139 & NS & $2.6(0.7-6.0) \mathrm{cm}$ & NS & $94.1 \%$ & $19 \%$ (5 years) & NS \\
\hline $\begin{array}{l}\text { Abdelaziz } \\
\text { et al. (149) }\end{array}$ & 2014 & 66 & $\begin{array}{l}37.9 \% \mathrm{~A} \\
62.1 \% \mathrm{~B}\end{array}$ & $2.9 \pm 0.97 \mathrm{~cm}$ & $\begin{array}{c}93.9 \% \text { right lobe, } 6.1 \% \text { left } \\
\text { lobe }\end{array}$ & $96.1 \%$ & $62 \%$ (2 years) & $\begin{array}{c}3.2 \% \text { (minor } \\
\text { complications); no } \\
\text { major complication }\end{array}$ \\
\hline $\begin{array}{l}\text { Medhat } \\
\text { et al. (129) }\end{array}$ & 2015 & 26 & $\begin{array}{l}73.1 \% \mathrm{~A} \\
27.9 \% \mathrm{~B}\end{array}$ & $5.57 \pm 0.73 \mathrm{~cm}$ & NS & $73.1 \%$ & Median 21.5 months & No major complication \\
\hline $\begin{array}{l}\text { Asvadi } \\
\text { et al. (137) }\end{array}$ & 2016 & 48 & NS & $2.4(0.9-5.2) \mathrm{cm}$ & Liver dome & $85 \%$ & $73.9 \%$ (2 years) & No major complication \\
\hline $\begin{array}{l}\text { Lee } \\
\text { et al. (125) }\end{array}$ & 2017 & 26 & $\begin{array}{l}88.5 \% \mathrm{~A} \\
11.5 \% \mathrm{~B}\end{array}$ & $3.75(2.0-6.0) \mathrm{cm}$ & NS & NS & $70 \%$ (3 years) & $\begin{array}{l}15.4 \% \text { (minor } \\
\text { complications) }\end{array}$ \\
\hline $\begin{array}{l}\text { Xu } \\
\text { et al. (124) }\end{array}$ & 2017 & 301 & $\begin{array}{c}92.4 \% \mathrm{~A} \\
7.6 \% \mathrm{~B}\end{array}$ & $1.7 \pm 0.3 \mathrm{~cm}$ & NS & $98.3 \%$ & $78.3 \%$ (5 years) & $\begin{array}{c}0.7 \% \text { (major } \\
\text { complications) }\end{array}$ \\
\hline $\begin{array}{l}\text { Santambrogio } \\
\text { et al. (126) }\end{array}$ & 2017 & 60 & $100 \% \mathrm{~A}$ & $2.15 \pm 0.53 \mathrm{~cm}$ & $\begin{array}{c}62 \% \text { at deep intrahepatic } \\
\text { location, } 37 \% \text { adjacent to } \\
\text { hepatic structures or other } \\
\text { viscera, } 7 \% \text { adjacent to major } \\
\text { vessels }\end{array}$ & $95 \%$ & $37 \%$ (5 years) & $\begin{array}{c}23 \% \text { (minor } \\
\text { complications); <2\% } \\
\text { (major complications) }\end{array}$ \\
\hline $\begin{array}{l}\text { Ding } \\
\text { et al. (139) }\end{array}$ & 2017 & 132 & $\begin{array}{c}91 \% \text { A, } 9 \% \\
B\end{array}$ & $2.52 \pm 0.83 \mathrm{~cm}$ & 71 exophytic growths & $96.6 \%$ & $61.5 \%$ (5 years) & No major complication \\
\hline
\end{tabular}

NS, not specified. 
Table 4 Comparison of RFA, HIFU and MWA

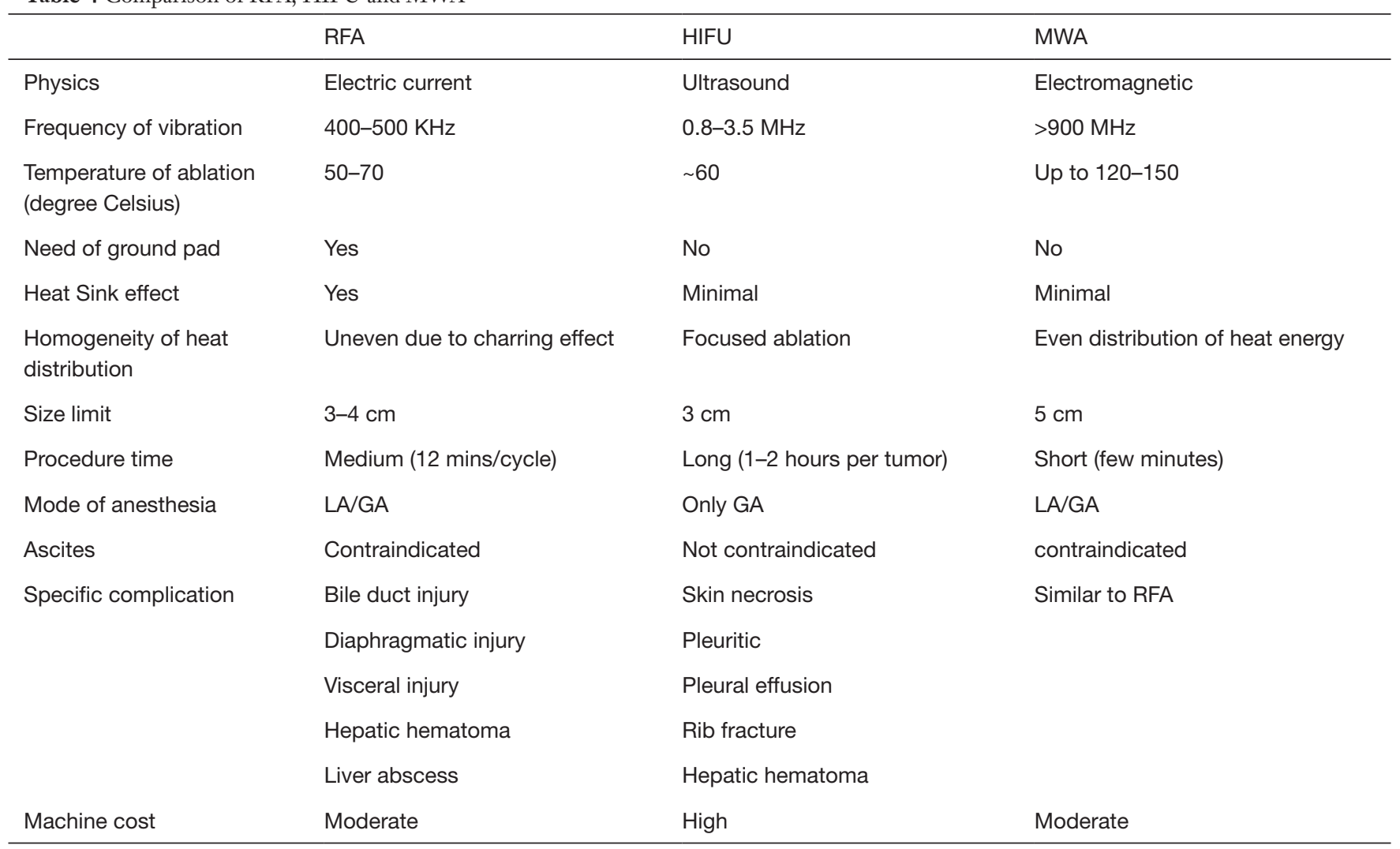

GA, general anesthesia; LA, local anesthesia.

\section{Summary and conclusions}

$\mathrm{RFA}$ is an indispensable part of the armamentarium for HCC treatment. It remains the most reliable means of ablative therapy. It represents an ideal alternative to hepatectomy in treating HCCs $<2-3 \mathrm{~cm}$ and a reasonable second choice in treating larger tumors. It plays an important role in bridging and down-staging therapies before transplantation. RFA will continue to be a popular treatment for both fit and frail patients, judging from its high safety profile and good post-treatment quality of life.

HIFU therapy is an emerging loco-ablative treatment option. It is an effective and safe treatment for cirrhotic HCC patients. As with other loco-ablative treatments, smaller HCCs usually have a better complete ablation rate. The combination of HIFU and TACE may provide good survival outcomes in patients with larger unresectable tumors, for which RFA is considered dangerous. On liver transplant waiting lists, HCC patients compete with liver failure patients. Their priority is inevitably lower than that of patients having high Model for End-Stage Liver Disease scores. Since HIFU has been shown to be well tolerated in patients with advanced cirrhosis, the use of HIFU as a bridging therapy is worth further evaluation.

MWA is a promising and emerging loco-ablative treatment option. It is an effective and safe treatment option for cirrhotic HCC patients. In general, small HCCs have higher response and complete ablation rates. With a more uniform ablative zone and no heat-sink effect, it may potentially offer advantages over RFA.

A comparison of these three modes of ablation is also shown in Table 4. Selective use of different loco-ablative therapies will enhance clinicians' treatment options for treatment of HCC.

\section{Acknowledgments}

Funding: None.

\section{Footnote}

Reporting Checklist: The authors have completed the Narrative Review reporting checklist. Available at 
https://hbsn.amegroups.com/article/view/10.21037/ hbsn.2020.03.11/rc

Conflicts of Interest: All authors have completed the ICMJE uniform disclosure form (available at https://hbsn. amegroups.com/article/view/10.21037/hbsn.2020.03.11/coif). The authors have no conflicts of interest to declare.

Ethical Statement: The authors are accountable for all aspects of the work in ensuring that questions related to the accuracy or integrity of any part of the work are appropriately investigated and resolved.

Open Access Statement: This is an Open Access article distributed in accordance with the Creative Commons Attribution-NonCommercial-NoDerivs 4.0 International License (CC BY-NC-ND 4.0), which permits the noncommercial replication and distribution of the article with the strict proviso that no changes or edits are made and the original work is properly cited (including links to both the formal publication through the relevant DOI and the license). See: https://creativecommons.org/licenses/by-nc-nd/4.0/.

\section{References}

1. Buscarini L, Rossi S, editors. Technology for radiofrequency thermal ablation of liver tumors. Seminars in laparoscopic surgery; 1997: Sage Publications Sage CA: Thousand Oaks, CA.

2. Buscarini E, Savoia A, Brambilla G, et al. Radiofrequency thermal ablation of liver tumors. Eur Radiol 2005;15:884-94.

3. Facciorusso A, Serviddio G, Muscatiello N. Local ablative treatments for hepatocellular carcinoma: An updated review. World J Gastrointest Pharmacol Ther 2016;7:477-89.

4. Huo TI, Huang YH, Wu JC, et al. Comparison of percutaneous acetic acid injection and percutaneous ethanol injection for hepatocellular carcinoma in cirrhotic patients: a prospective study. Scand J Gastroenterol 2003;38:770-8.

5. Lin XZ, Jen CM, Sung MZ, et al. Electrochemical therapy--comparison with other local treatment methods on rat model. Hepatogastroenterology 2001;48:91-4.

6. Poon RTP, Fan ST, Tsang FHF, et al. Locoregional therapies for hepatocellular carcinoma: a critical review from the surgeon's perspective. Ann Surg 2002;235:466.

7. Livraghi T, Bolondi L, Lazzaroni S, et al. Percutaneous ethanol injection in the treatment of hepatocellular carcinoma in cirrhosis. A study on 207 patients. Cancer 1992;69:925-9.
8. Ebara M, Ohto M, Sugiura N, et al. Percutaneous ethanol injection for the treatment of small hepatocellular carcinoma. Study of 95 patients. J Gastroenterol Hepatol 1990;5:616-26.

9. Stasi MD, Buscarini L, Livraghi T, et al. Percutaneous ethanol injection in the treatment of hepatocellular carcinoma: a multicenter survey of evaluation practices and complication rates. Scand J Gastroenterol 1997;32:1168-73.

10. Weis S, Franke A, Mossner J, et al. Radiofrequency (thermal) ablation versus no intervention or other interventions for hepatocellular carcinoma. Cochrane Database Syst Rev 2013;(12):CD003046.

11. Majumdar A, Roccarina D, Thorburn D, et al. Management of people with early- or very early-stage hepatocellular carcinoma: an attempted network metaanalysis. Cochrane Database Syst Rev 2017;3:CD011650.

12. Cho YK, Kim JK, Kim MY, et al. Systematic review of randomized trials for hepatocellular carcinoma treated with percutaneous ablation therapies. Hepatology 2009;49:453-9.

13. Orlando A, Leandro G, Olivo M, et al. Radiofrequency thermal ablation vs. percutaneous ethanol injection for small hepatocellular carcinoma in cirrhosis: meta-analysis of randomized controlled trials. Am J Gastroenterol 2009;104:514-24.

14. Ravikumar TS, Steele GD. Hepatic cryosurgery. Surg Clin North Am 1989;69:433-40.

15. Zhou XD, Tang ZY, Yu YQ, et al. Clinical evaluation of cryosurgery in the treatment of primary liver cancer. Report of 60 cases. Cancer 1988;61:1889-92.

16. Adam R, Akpinar E, Johann M, et al. Place of cryosurgery in the treatment of malignant liver tumors. Ann Surg 1997;225:39-48; discussion 48-50.

17. Lam CM, Yuen WK, Fan ST. Hepatic cryosurgery for recurrent hepatocellular carcinoma after hepatectomy: a preliminary report. J Surg Oncol 1998;68:104-6.

18. Seifert JK, Junginger T, Morris DL. A collective review of the world literature on hepatic cryotherapy. J R Coll Surg Edinb 1998;43:141-54.

19. Wren SM, Coburn MM, Tan M, et al. Is cryosurgical ablation appropriate for treating hepatocellular cancer? Arch Surg 1997;132:599-603; discussion 603-4.

20. Wong WS, Patel SC, Cruz FS, et al. Cryosurgery as a treatment for advanced stage hepatocellular carcinoma. Cancer 1998;82:1268-78.

21. Rong G, Bai W, Dong Z, et al. Long-term outcomes of percutaneous cryoablation for patients with hepatocellular carcinoma within Milan criteria. PLoS One 2015;10:e123065.

22. Chen MS, Li JQ, Zheng Y, et al. A prospective randomized trial comparing percutaneous local ablative therapy and 
partial hepatectomy for small hepatocellular carcinoma. Ann Surg 2006;243:321-8.

23. Feng K, Yan J, Li X, et al. A randomized controlled trial of radiofrequency ablation and surgical resection in the treatment of small hepatocellular carcinoma. J Hepatol 2012;57:794-802.

24. Mazzaferro V, Regalia E, Doci R, et al. Liver transplantation for the treatment of small hepatocellular carcinomas in patients with cirrhosis. N Engl J Med 1996;334:693-9.

25. Huang J, Yan L, Cheng Z, et al. A randomized trial comparing radiofrequency ablation and surgical resection for HCC conforming to the Milan criteria. Ann Surg 2010;252:903-12.

26. Liu PH, Hsu CY, Hsia CY, et al. Surgical Resection Versus Radiofrequency Ablation for Single Hepatocellular Carcinoma $</=2 \mathrm{~cm}$ in a Propensity Score Model. Ann Surg 2016;263:538-45.

27. Kim GA, Shim JH, Kim MJ, et al. Radiofrequency ablation as an alternative to hepatic resection for single small hepatocellular carcinomas. Br J Surg 2016;103:126-35.

28. Kutlu OC, Chan JA, Aloia TA, et al. Comparative effectiveness of first-line radiofrequency ablation versus surgical resection and transplantation for patients with early hepatocellular carcinoma. Cancer 2017;123:1817-27.

29. Huang G, Chen X, Lau WY, et al. Quality of life after surgical resection compared with radiofrequency ablation for small hepatocellular carcinomas. Br J Surg 2014;101:1006-15.

30. Bowles BJ, Machi J, Limm WM, et al. Safety and efficacy of radiofrequency thermal ablation in advanced liver tumors. Arch Surg 2001;136:864-9.

31. Dai WC, Cheung TT, Chok KS, et al. Radiofrequency ablation versus transarterial chemoembolization for unresectable solitary hepatocellular carcinomas sized 5-8 cm. HPB (Oxford) 2015;17:226-31.

32. Livraghi T, Meloni F, Di Stasi M, et al. Sustained complete response and complications rates after radiofrequency ablation of very early hepatocellular carcinoma in cirrhosis: Is resection still the treatment of choice? Hepatology 2008;47:82-9.

33. Sala M, Llovet JM, Vilana R, et al. Initial response to percutaneous ablation predicts survival in patients with hepatocellular carcinoma. Hepatology 2004;40:1352-60.

34. Tateishi R, Shiina S, Teratani T, et al. Percutaneous radiofrequency ablation for hepatocellular carcinoma. An analysis of 1000 cases. Cancer 2005;103:1201-9.

35. Poon RT, Ng KK, Lam C-M, et al. Effectiveness of radiofrequency ablation for hepatocellular carcinomas larger than $3 \mathrm{~cm}$ in diameter. Arch Surg 2004;139:281-7.

36. Patterson EJ, Scudamore CH, Owen DA, et al. Radiofrequency ablation of porcine liver in vivo: effects of blood flow and treatment time on lesion size. Ann Surg 1998;227:559.

37. Ogawa T, Kawamoto H, Kobayashi Y, et al. Prevention of biliary complication in radiofrequency ablation for hepatocellular carcinoma-Cooling effect by endoscopic nasobiliary drainage tube. Eur J Radiol 2010;73:385-90.

38. Elias D, Sideris L, Pocard M, et al. Intraductal cooling of the main bile ducts during radiofrequency ablation prevents biliary stenosis. J Am Coll Surg 2004;198:717-21.

39. Jarnagin WR. Blumgart's Surgery of the Liver, Pancreas and Biliary Tract E-Book: Expert Consult-Online. Elsevier Health Sciences; 2012.

40. Goldberg SN, Gazelle GS. Radiofrequency tissue ablation: physical principles and techniques for increasing coagulation necrosis. Hepatogastroenterology 2001;48:359-67.

41. Livraghi T, Goldberg SN, Lazzaroni S, et al. Hepatocellular carcinoma: radio-frequency ablation of medium and large lesions. Radiology 2000;214:761-8.

42. Rossi S, Garbagnati F, Lencioni R, et al. Percutaneous radio-frequency thermal ablation of nonresectable hepatocellular carcinoma after occlusion of tumor blood supply. Radiology 2000;217:119-26.

43. Buscarini L, Buscarini E, Di Stasi M, et al. Percutaneous radiofrequency thermal ablation combined with transcatheter arterial embolization in the treatment of large hepatocellular carcinoma. Ultraschall Med 1999;20:47-53.

44. Ni JY, Liu SS, Xu LF, et al. Meta-analysis of radiofrequency ablation in combination with transarterial chemoembolization for hepatocellular carcinoma. World J Gastroenterol 2013;19:3872-82.

45. DuBay D, Sandroussi C, Sandhu L, et al. Liver transplantation for advanced hepatocellular carcinoma using poor tumor differentiation on biopsy as an exclusion criterion. Ann Surg 2011;253:166-72.

46. Shah SA, Cleary SP, Tan JC, et al. An analysis of resection vs transplantation for early hepatocellular carcinoma: defining the optimal therapy at a single institution. Ann Surg Oncol 2007;14:2608-14.

47. Freeman RB, Edwards EB, Harper AM. Waiting list removal rates among patients with chronic and malignant liver diseases. Am J Transplant 2006;6:1416-21.

48. Bruix J, Sherman M. Management of hepatocellular 
carcinoma: an update. Hepatology 2011;53:1020-2.

49. Lee MW, Raman SS, Asvadi NH, et al. Radiofrequency ablation of hepatocellular carcinoma as bridge therapy to liver transplantation: A 10-year intention-to-treat analysis. Hepatology 2017;65:1979-90.

50. Lu DS, Yu NC, Raman SS, et al. Percutaneous radiofrequency ablation of hepatocellular carcinoma as a bridge to liver transplantation. Hepatology 2005;41:1130-7.

51. Chan KM, Yu MC, Chou HS, et al. Significance of tumor necrosis for outcome of patients with hepatocellular carcinoma receiving locoregional therapy prior to liver transplantation. Ann Surg Oncol 2011;18:2638-46.

52. Barakat O, Wood RP, Ozaki CF, et al. Morphological features of advanced hepatocellular carcinoma as a predictor of downstaging and liver transplantation: an intention-to-treat analysis. Liver Transpl 2010;16:289-99.

53. Yao FY, Kerlan RK, Jr., Hirose R, et al. Excellent outcome following down-staging of hepatocellular carcinoma prior to liver transplantation: an intention-to-treat analysis. Hepatology 2008;48:819-27.

54. Ravaioli M, Grazi G, Piscaglia F, et al. Liver transplantation for hepatocellular carcinoma: results of down-staging in patients initially outside the Milan selection criteria. Am J Transplant 2008;8:2547-57.

55. Cillo U, Vitale A, Grigoletto F, et al. Intention-to-treat analysis of liver transplantation in selected, aggressively treated HCC patients exceeding the Milan criteria. Am J Transplant 2007;7:972-81.

56. Lu MD, Yin XY, Xie XY, et al. Percutaneous thermal ablation for recurrent hepatocellular carcinoma after hepatectomy. Br J Surg 2005;92:1393-8.

57. Liang HH, Chen MS, Peng ZW, et al. Percutaneous radiofrequency ablation versus repeat hepatectomy for recurrent hepatocellular carcinoma: a retrospective study. Ann Surg Oncol 2008;15:3484-93.

58. Erridge S, Pucher PH, Markar SR, et al. Meta-analysis of determinants of survival following treatment of recurrent hepatocellular carcinoma. Br J Surg 2017;104:1433-42.

59. Cheung TT, Poon RT, Chok KS, et al. Management of spontaneously ruptured hepatocellular carcinomas in the radiofrequency ablation era. PLoS One 2014;9:e94453.

60. Cherqui D, Panis Y, Rotman N, et al. Emergency liver resection for spontaneous rupture of hepatocellular carcinoma complicating cirrhosis. Br J Surg 1993;80:747-9.

61. Curley SA, Marra P, Beaty K, et al. Early and late complications after radiofrequency ablation of malignant liver tumors in 608 patients. Ann Surg 2004;239:450-8.

62. Kasugai H, Osaki Y, Oka H, et al. Severe complications of radiofrequency ablation therapy for hepatocellular carcinoma: an analysis of 3,891 ablations in 2,614 patients. Oncology 2007;72 Suppl 1:72-5.

63. Mulier S, Mulier P, Ni Y, et al. Complications of radiofrequency coagulation of liver tumours. Br J Surg 2002;89:1206-22

64. Cheung TT, Ng KK, Chok KS, et al. Combined resection and radiofrequency ablation for multifocal hepatocellular carcinoma: prognosis and outcomes. World J Gastroenterol 2010;16:3056-62.

65. Brunello F, Veltri A, Carucci P, et al. Radiofrequency ablation versus ethanol injection for early hepatocellular carcinoma: A randomized controlled trial. Scand J Gastroenterol 2008;43:727-35.

66. Lin SM, Lin CJ, Lin CC, et al. Randomised controlled trial comparing percutaneous radiofrequency thermal ablation, percutaneous ethanol injection, and percutaneous acetic acid injection to treat hepatocellular carcinoma of 3 cm or less. Gut 2005;54:1151-6.

67. Seror O, N'Kontchou G, Tin Tin Htar M, et al. Ethanol versus radiofrequency ablation for the treatment of small hepatocellular carcinoma in patients with cirrhosis: a retrospective study of efficacy and cost. Gastroenterol Clin Biol 2006;30:1265-73.

68. Shiina S, Teratani T, Obi S, et al. A randomized controlled trial of radiofrequency ablation with ethanol injection for small hepatocellular carcinoma. Gastroenterology 2005;129:122-30.

69. Ng KKC, Chok KSH, Chan ACY, et al. Randomized clinical trial of hepatic resection versus radiofrequency ablation for early-stage hepatocellular carcinoma. Br J Surg 2017;104:1775-84.

70. de Baere T, Risse O, Kuoch V, et al. Adverse events during radiofrequency treatment of 582 hepatic tumors. AJR Am J Roentgenol 2003;181:695-700.

71. Livraghi T, Solbiati L, Meloni MF, et al. Treatment of focal liver tumors with percutaneous radio-frequency ablation: complications encountered in a multicenter study. Radiology 2003;226:441-51.

72. Zagoria RJ, Chen MY, Shen P, et al. Complications from radiofrequency ablation of liver metastases. Am Surg 2002;68:204-9.

73. Curley SA. Radiofrequency ablation of malignant liver tumors. Ann Surg Oncol 2003;10:338-47.

74. Llovet JM, Vilana R, Bru C, et al. Increased risk of tumor seeding after percutaneous radiofrequency ablation for single hepatocellular carcinoma. Hepatology 2001;33:1124-9. 
75. Lynn JG, Zwemer RL, Chick AJ, et al. A New Method for the Generation and Use of Focused Ultrasound in Experimental Biology. J Gen Physiol 1942;26:179-93.

76. Barnard JW, Fry WJ, Fry FJ, et al. Effects of high intensity ultrasound on the central nervous system of the cat. J Comp Neurol 1955;103:459-84.

77. Fry WJ, Mosberg WH Jr, Barnard JW, et al. Production of focal destructive lesions in the central nervous system with ultrasound. J Neurosurg 1954;11:471-8.

78. Wang ZB, Wu F, Wang ZL, et al. Targeted damage effects of high intensity focused ultrasound (HIFU) on liver tissues of Guizhou Province miniswine. Ultrason Sonochem 1997;4:181-2.

79. Clement GT. Perspectives in clinical uses of high-intensity focused ultrasound. Ultrasonics 2004;42:1087-93.

80. Wu F, Wang Z, Chen W. Pathological study of extracorporeally ablated hepatocellular carcinoma with high-intensity focused ultrasound. Zhonghua Zhong Liu Za Zhi 2001;23:237-9.

81. Ng KK, Poon RT, Chan SC, et al. High-intensity focused ultrasound for hepatocellular carcinoma: a single-center experience. Ann Surg 2011;253:981-7.

82. Xu G, Luo G, He L, et al. Follow-up of highintensity focused ultrasound treatment for patients with hepatocellular carcinoma. Ultrasound Med Biol 2011;37:1993-9.

83. Cheung TT, Fan ST, Chu FS, et al. Survival analysis of high-intensity focused ultrasound ablation in patients with small hepatocellular carcinoma. HPB (Oxford) 2013;15:567-73.

84. Llovet JM, Bruix J. Novel advancements in the management of hepatocellular carcinoma in 2008. J Hepatol 2008;48 Suppl 1:S20-37.

85. Llovet JM, Ricci S, Mazzaferro V, et al. Sorafenib in advanced hepatocellular carcinoma. N Engl J Med 2008;359:378-90.

86. Matsui O. Current status of hepatocellular carcinoma treatment in Japan: transarterial chemoembolization. Clin Drug Investig 2012;32 Suppl 2:3-13.

87. Molinari M, Kachura JR, Dixon E, et al. Transarterial chemoembolisation for advanced hepatocellular carcinoma: results from a North American cancer centre. Clin Oncol (R Coll Radiol) 2006;18:684-92.

88. Satake M, Uchida H, Arai Y, et al. Transcatheter arterial chemoembolization (TACE) with lipiodol to treat hepatocellular carcinoma: survey results from the TACE study group of Japan. Cardiovasc Intervent Radiol 2008;31:756-61.
89. Lo CM, Ngan H, Tso WK, et al. Randomized controlled trial of transarterial lipiodol chemoembolization for unresectable hepatocellular carcinoma. Hepatology 2002;35:1164-71.

90. Wu F, Wang ZB, Chen WZ, et al. Extracorporeal high intensity focused ultrasound ablation in the treatment of patients with large hepatocellular carcinoma. Ann Surg Oncol 2004;11:1061-9.

91. Li YY, Sha WH, Zhou YJ, et al. Short and long term efficacy of high intensity focused ultrasound therapy for advanced hepatocellular carcinoma. J Gastroenterol Hepatol 2007;22:2148-54.

92. Cheung TT, Poon RT, Jenkins CR, et al. Survival analysis of high-intensity focused ultrasound therapy vs. transarterial chemoembolization for unresectable hepatocellular carcinomas. Liver Int 2014;34:e136-43.

93. Wu F, Wang ZB, Chen WZ, et al. Advanced hepatocellular carcinoma: treatment with high-intensity focused ultrasound ablation combined with transcatheter arterial embolization. Radiology 2005;235:659-67.

94. Li C, Zhang W, Zhang R, et al. Therapeutic effects and prognostic factors in high-intensity focused ultrasound combined with chemoembolisation for larger hepatocellular carcinoma. Eur J Cancer 2010;46:2513-21.

95. Lencioni R, Crocetti L, Cioni D, et al. Percutaneous radiofrequency ablation of hepatic colorectal metastases: technique, indications, results, and new promises. Invest Radiol 2004;39:689-97.

96. Zhang L, Zhu H, Jin C, et al. High-intensity focused ultrasound (HIFU): effective and safe therapy for hepatocellular carcinoma adjacent to major hepatic veins. Eur Radiol 2009;19:437-45.

97. Cheung TT, Chok KS, Lo RC, et al. High-intensity focused ultrasound ablation as a bridging therapy for hepatocellular carcinoma patients awaiting liver transplantation. Hepatobiliary Pancreat Dis Int 2012;11:542-4.

98. Cheung TT, Poon RT, Yau T, et al. High-intensity focused ultrasound as a treatment for colorectal liver metastasis in difficult position. Int J Colorectal Dis 2012;27:987-8.

99. Cheung TT, Fan ST, Chan SC, et al. High-intensity focused ultrasound ablation: an effective bridging therapy for hepatocellular carcinoma patients. World J Gastroenterol 2013;19:3083-9.

100.Li JJ, Xu GL, Gu MF, et al. Complications of high intensity focused ultrasound in patients with recurrent and metastatic abdominal tumors. World J Gastroenterol 2007;13:2747-51. 
101. Cheung TT, Chu FS, Jenkins CR, et al. Tolerance of highintensity focused ultrasound ablation in patients with hepatocellular carcinoma. World J Surg 2012;36:2420-7.

102. Simon CJ, Dupuy DE, Mayo-Smith WW. Microwave ablation: principles and applications. Radiographics 2005;25 Suppl 1:S69-83.

103. Simo KA, Tsirline VB, Sindram D, et al. Microwave ablation using $915-\mathrm{MHz}$ and $2.45-\mathrm{GHz}$ systems: what are the differences? HPB (Oxford) 2013;15:991-6.

104. Saitsu H, Mada Y, Taniwaki S, et al. Investigation of microwave coagulo-necrotic therapy for 21 patients with small hepatocellular carcinoma less than $5 \mathrm{~cm}$ in diameter. Nihon Geka Gakkai Zasshi 1993;94:359-65.

105.Seki T, Wakabayashi M, Nakagawa T, et al. Ultrasonically guided percutaneous microwave coagulation therapy for small hepatocellular carcinoma. Cancer 1994;74:817-25.

106. Watanabe Y, Sato M, Abe Y, et al. Laparoscopic microwave coagulo-necrotic therapy for hepatocellular carcinoma: a feasible study of an alternative option for poor-risk patients. J Laparoendosc Surg 1995;5:169-75.

107. Tabuse K, Katsumi M. Application of a microwave tissue coagulator to hepatic surgery the hemostatic effects on spontaneous rupture of hepatoma and tumor necrosis. Nihon Geka Hokan 1981;50:571-9.

108. Tabuse K, Katsumi M, Kobayashi Y, et al. Microwave surgery: hepatectomy using a microwave tissue coagulator. World J Surg 1985;9:136-43.

109. Wright AS, Sampson LA, Warner TF, et al. Radiofrequency versus microwave ablation in a hepatic porcine model. Radiology 2005;236:132-9.

110. Carrafiello G, Lagana D, Mangini M, et al. Microwave tumors ablation: principles, clinical applications and review of preliminary experiences. Int J Surg 2008;6 Suppl 1:S65-9.

111. Noguchi H. Experimental studies of anti-tumor effect induced by microwave tumor coagulation. Nihon Geka Hokan 1984;53:324-37.

112. Brace CL. Microwave tissue ablation: biophysics, technology, and applications. Crit Rev Biomed Eng 2010;38:65-78.

113. Ward RC, Healey TT, Dupuy DE. Microwave ablation devices for interventional oncology. Expert Rev Med Devices 2013;10:225-38.

114. Bruix J, Sherman M, American Association for the Study of Liver D. Management of hepatocellular carcinoma: an update. Hepatology 2011;53:1020-2.

115.Qian GJ, Wang N, Shen Q, et al. Efficacy of microwave versus radiofrequency ablation for treatment of small hepatocellular carcinoma: experimental and clinical studies. Eur Radiol 2012;22:1983-90.

116. Shiina S, Tateishi R, Arano T, et al. Radiofrequency ablation for hepatocellular carcinoma: 10-year outcome and prognostic factors. Am J Gastroenterol 2012;107:56977; quiz 78.

117. Kim YS, Lim HK, Rhim H, et al. Ten-year outcomes of percutaneous radiofrequency ablation as first-line therapy of early hepatocellular carcinoma: analysis of prognostic factors. J Hepatol 2013;58:89-97.

118. Lee DH, Lee JM, Lee JY, et al. Radiofrequency ablation of hepatocellular carcinoma as first-line treatment: longterm results and prognostic factors in 162 patients with cirrhosis. Radiology 2014;270:900-9.

119. Kuang M, Xie XY, Huang C, et al. Long-term outcome of percutaneous ablation in very early-stage hepatocellular carcinoma. J Gastrointest Surg 2011;15:2165-71.

120.Peng ZW, Lin XJ, Zhang YJ, et al. Radiofrequency ablation versus hepatic resection for the treatment of hepatocellular carcinomas $2 \mathrm{~cm}$ or smaller: a retrospective comparative study. Radiology 2012;262:1022-33.

121. Wang JH, Wang CC, Hung CH, et al. Survival comparison between surgical resection and radiofrequency ablation for patients in BCLC very early/early stage hepatocellular carcinoma. J Hepatol 2012;56:412-8.

122. Roayaie S, Obeidat K, Sposito C, et al. Resection of hepatocellular cancer $</=2 \mathrm{~cm}$ : results from two Western centers. Hepatology 2013;57:1426-35.

123. Pompili M, De Matthaeis N, Saviano A, et al. Single hepatocellular carcinoma smaller than $2 \mathrm{~cm}$ : are ethanol injection and radiofrequency ablation equally effective? Anticancer Res 2015;35:325-32.

124.Xu Y, Shen Q, Wang N, et al. Microwave ablation is as effective as radiofrequency ablation for very-early-stage hepatocellular carcinoma. Chin J Cancer 2017;36:14.

125.Lee KF, Wong J, Hui JW, et al. Long-term outcomes of microwave versus radiofrequency ablation for hepatocellular carcinoma by surgical approach: A retrospective comparative study. Asian J Surg 2017;40:301-8.

126. Santambrogio R, Chiang J, Barabino M, et al. Comparison of Laparoscopic Microwave to Radiofrequency Ablation of Small Hepatocellular Carcinoma $(</=3 \mathrm{~cm})$. Ann Surg Oncol 2017;24:257-63.

127. Groeschl RT, Pilgrim CH, Hanna EM, et al. Microwave ablation for hepatic malignancies: a multiinstitutional analysis. Ann Surg 2014;259:1195-200. 
128. Brace CL. Dual-slot antennas for microwave tissue heating: parametric design analysis and experimental validation. Med Phys 2011;38:4232-40.

129. Medhat E, Abdel Aziz A, Nabeel M, et al. Value of microwave ablation in treatment of large lesions of hepatocellular carcinoma. J Dig Dis 2015;16:456-63.

130. Yin XY, Xie XY, Lu MD, et al. Percutaneous thermal ablation of medium and large hepatocellular carcinoma: long-term outcome and prognostic factors. Cancer 2009; 115:1914-23.

131.Liu Y, Zheng Y, Li S, et al. Percutaneous microwave ablation of larger hepatocellular carcinoma. Clin Radiol 2013;68:21-6.

132.Lahat E, Eshkenazy R, Zendel A, et al. Complications after percutaneous ablation of liver tumors: a systematic review. Hepatobiliary Surg Nutr 2014;3:317-23.

133. Fonseca AZ, Santin S, Gomes LG, et al. Complications of radiofrequency ablation of hepatic tumors: Frequency and risk factors. World J Hepatol 2014;6:107-13.

134. Howenstein MJ, Sato KT. Complications of radiofrequency ablation of hepatic, pulmonary, and renal neoplasms. Semin Intervent Radiol 2010;27:285-95.

135.Zhi-Yu H, Ping L, Xiao-Ling Y, et al. A clinical study of thermal monitoring techniques of ultrasound-guided microwave ablation for hepatocellular carcinoma in highrisk locations. Sci Rep 2017;7:41246.

136. Sato M, Watanabe Y, Tokui K, et al. CT-guided treatment of ultrasonically invisible hepatocellular carcinoma. Am J Gastroenterol 2000;95:2102-6.

137.Asvadi NH, Anvari A, Uppot RN, et al. CT-Guided Percutaneous Microwave Ablation of Tumors in the Hepatic Dome: Assessment of Efficacy and Safety. J Vasc Interv Radiol 2016;27:496-502; quiz 503.

138. Kotoh K, Nakamuta M, Morizono S, et al. A multistep, incremental expansion method for radio frequency ablation: optimization of the procedure to prevent increases in intra-tumor pressure and to reduce the ablation time. Liver Int 2005;25:542-7.

139. Ding J, Zhou Y, Wang Y, et al. Percutaneous microwave ablation of exophytic tumours in hepatocellular carcinoma patients: Safe or not? Liver Int 2017;37:1365-72.

140.Song I, Rhim H, Lim HK, et al. Percutaneous radiofrequency ablation of hepatocellular carcinoma abutting the diaphragm and gastrointestinal tracts with the use of artificial ascites: safety and technical efficacy in 143 patients. Eur Radiol 2009;19:2630-40.

141.Kang TW, Rhim H, Lee MW, et al. Radiofrequency ablation for hepatocellular carcinoma abutting the diaphragm: comparison of effects of thermal protection and therapeutic efficacy. AJR Am J Roentgenol 2011;196:907-13.

142. Llovet JM, Fuster J, Bruix J. Intention-to-treat analysis of surgical treatment for early hepatocellular carcinoma: resection versus transplantation. Hepatology 1999;30:1434-40.

143. Yao FY, Bass NM, Nikolai B, et al. Liver transplantation for hepatocellular carcinoma: analysis of survival according to the intention-to-treat principle and dropout from the waiting list. Liver Transpl 2002;8:873-83.

144.Pompili M, Francica G, Ponziani FR, et al. Bridging and downstaging treatments for hepatocellular carcinoma in patients on the waiting list for liver transplantation. World J Gastroenterol 2013;19:7515-30.

145.Zhang L, Wang N, Shen Q, et al. Therapeutic efficacy of percutaneous radiofrequency ablation versus microwave ablation for hepatocellular carcinoma. PLoS One 2013;8:e76119.

146.Zanus G, Boetto R, Gringeri E, et al. Microwave thermal ablation for hepatocarcinoma: six liver transplantation cases. Transplant Proc 2011;43:1091-4.

147. Vasnani R, Ginsburg M, Ahmed O, et al. Radiofrequency and microwave ablation in combination with transarterial chemoembolization induce equivalent histopathologic coagulation necrosis in hepatocellular carcinoma patients bridged to liver transplantation. Hepatobiliary Surg Nutr 2016;5:225-33.

148. Peng ZW, Zhang YJ, Chen MS, et al. Radiofrequency ablation with or without transcatheter arterial chemoembolization in the treatment of hepatocellular carcinoma: a prospective randomized trial. J Clin Oncol 2013;31:426-32.

149.Abdelaziz A, Elbaz T, Shousha HI, et al. Efficacy and survival analysis of percutaneous radiofrequency versus microwave ablation for hepatocellular carcinoma: an Egyptian multidisciplinary clinic experience. Surg Endosc 2014;28:3429-34.

150.Seki T, Wakabayashi M, Nakagawa T, et al. Percutaneous microwave coagulation therapy for patients with small hepatocellular carcinoma: comparison with percutaneous ethanol injection therapy. Cancer 1999;85:1694-702.

151. Shibata T, Iimuro Y, Yamamoto Y, et al. Small hepatocellular carcinoma: comparison of radio-frequency ablation and percutaneous microwave coagulation therapy. Radiology 2002;223:331-7.

152.Liang P, Dong B, Yu X, et al. Prognostic factors for survival in patients with hepatocellular carcinoma 
after percutaneous microwave ablation. Radiology 2005;235:299-307.

153. Ohmoto K, Yoshioka N, Tomiyama Y, et al. Comparison of therapeutic effects between radiofrequency ablation and percutaneous microwave coagulation therapy for

Cite this article as: Cheung TT, Ma KW, She WH. A review on radiofrequency, microwave and high-intensity focused ultrasound ablations for hepatocellular carcinoma with cirrhosis. HepatoBiliary Surg Nutr 2021;10(2):193-209. doi: 10.21037/ hbsn.2020.03.11 small hepatocellular carcinomas. J Gastroenterol Hepatol 2009;24:223-7.

154. Ding J, Jing X, Liu J, et al. Comparison of two different thermal techniques for the treatment of hepatocellular carcinoma. Eur J Radiol 2013;82:1379-84. 